\title{
DEVELOPING MODULE OF CHILDREN LITERATURE TO INCREASE THE STUDENTS' CRITICAL THINKING
}

\author{
Hajarudin Alfikri', Enny Zubaidah ${ }^{2}$ \\ 1,2Universitas Negeri Yogyakarta \\ 1,2Jl. Colombo No.1, Karang Malang, Daerah Istimewa Yogyakarta \\ Email: hajaralfikridikdas@gmail.com ${ }^{1}$, enny.zubaidah@gmail.com²
}

\begin{abstract}
:
This study aimed to (1) produce a module of children literature based on nationalism character to improve the critical thinking ability of the fourth grade students of MIN Boyolali, and (2) measure the effectiveness of the module used in classroom toward critical thinking ability of the fourth grade students of MIN Boyolali. Set within the research and development type, this study adapted the development procedure formulated by Borg and Gall (1983). Data were collected through interview and observation, product validation, questionnaire of the teacher and the students' response, and the result of pre-test and post-test which was analyzed using independent sample t-test. Meanwhile, the effectiveness was tested through quasi experiment. The result of the research showed that the module was categorized as "fit" by material and language expert; while the media expert categorized it as "very fit". In the other hand, the teacher and the students' responses to the use of learning module were categorized as "excellent". Further, the output of the independent sample $t$ test showed that the module was effective to improve the students' critical thinking skills.
\end{abstract}

\begin{abstract}
Abstrak:
Penelitian ini bertujuan untuk (1) menghasilkan modul sastra anak berdasarkan karakter nasionalisme untuk meningkatkan kemampuan berpikir kritis siswa kelas IV MIN Boyolali, dan (2) mengukur efektivitas modul yang digunakan di kelas terhadap kemampuan berpikir kritis siswa kelas IV MIN Boyolali. Penelitian ini adalah jenis penelitian pengembangan yang mengadaptasi prosedur pengembangan yang dirumuskan oleh Borg dan Gall (1983). Data dikumpulkan melalui wawancara dan observasi, validasi produk, kuesioner dari guru dan respon siswa, dan hasil pre-test dan post-test yang dianalisis menggunakan independent sample t-test. Sementara itu, keefektifannya diuji melalui eksperimen semu. Hasil penelitian menunjukkan bahwa modul dikategorikan "cocok" oleh ahli materi dan bahasa; sedangkan pakar media mengategorikannya "sangat pas". Di sisi lain, respons guru dan siswa terhadap penggunaan modul pembelajaran dikategorikan "sangat baik". Selanjutnya, hasil dari uji $\mathrm{t}$ sampel independen menunjukkan bahwa modul ini efektif untuk meningkatkan keterampilan berpikir kritis siswa
\end{abstract}

\section{Keywords: \\ Module, Children Literature, Critical Thingking Ability}

THE demoralization phenomenon that is increasingly massive in the world of education can be easily found. Starting from the finding of textbooks for elementary school students (SD) containing inappropriate content until the case of an elementary school student was impregnated by a junior high school student. It is the evidence 
that the increase of educational participation has not been fully followed by the improvement of character and noble attitude that can build a strong shape of the nation. Character education has an important role in character building efforts in a broad sense involving ministries, society, schools and parents to support the realization of a nation civilization which is superior and noble. The phenomenon of weakening of such a character is very alarming. Lickona (1991) reveals that there are ten signs of the times to watch out because if these signs already exist, it means that a nation is heading to destruction. Those signs are: (1) increasing violence among adolescents, (2) the use of inapproppriate language and words, (3) strong peer group influence in violence, (4) increasing self-destructive behavior, such as the use of drugs, alcohol, and free sex behavior (5) the blurring between the good and bad moral norms, (6) decrease in work ethic, (7) the low respect toward parents and teachers, (8) the low responsibility of individuals and citizens, (9) increase of dishonesty, (10) the sense of mutual suspicion and hatred against others. The same symptoms can be found as presented by Lickona above with the conditions present in the elementary school at this time. Behaviors of disrespect of elementary students to parents and teachers, cheating on exams, bullying children, and their familiarity with sarcasm words and cigarette can be found easily; although this is not an attempt to generalize the character of all elementary students.

One way that can be used to shape character is through the learning of children literature in elementary school. The students who study literature can learn to understand their friends, learn empathy between friends, and can understand the moral of an event narrated through characterization in children literature (Tomlison \& Brown, 2002: 4). Supporting that opinion, Saracho and Spodek (2010: 401) also reinforces that children literature helps students to connect the emotions through aesthetic experiences while engaging in the story. Children literature in elementary school cannot be separated from Indonesian subject in elementary school. This close linkage is due to the fact that the teaching of children literature has been delivered in a limited way only with the portion of 10\% (Wibowo, 2013: 22). Such expressed views are in contrast to the existence of Bahasa in the integrative thematic curriculum 2013, which provides an advantage to children literature learning since its materials delivered through Bahasa get more opportunities to be taught by linking them to other subjects such as social studies, mathematics, and science.

According to Zuchdi (2009), the activities of using language which is the domain of Bahasa, including listening, reading, speaking, and writing, other linguistic forms learned, as well as literary appreciation, are integrated comprehensively and are incorporated into the themes which also cover the target values to be developed. This implies that the use of children literature can also be related to subjects other than Bahasa, so that the teaching of characters through children literature gets the widest possible opportunity. However, learning practices that occur in the classroom, teachers rarely give the content of the character value of the subject matter that is delivered through the children literature. 
The significance of children literature in learning is not only limited to its ability as a media to instill characters, but more than that, it also contributes significantly to the cognitive development of the students as it contains not only personal value, but also academic one (Tomlison \& Brown, 2002: 3-8). Regarding the function of children's literature in terms of cognitive enhancement, Saxby and Gordo (1991: 8) states that it provides hard-knowledge \& soft-knowledge simultaneously. Hardknowledge in literature is connected to fact and data while soft-knowledge is related to human heart, both of which cannot be found in the laboratory but through life experiences. Such a life experience is expressed metaphorically in children literature. Further, Chen (2012: 89) conveyed that the literature of children can also be used to improve the students' thinking ability up to the stage of critical thinking. Critical thinking appears as students' response to what they read, especially in the form of literature which is metaphorical in nature and full of logic of causality. Children can also criticize it by guessing, finding evidence, reasoning, finding a way out of the difficulties faced by the character in the story, including predicting how the story will be solved.

Based on the documentation of the study conducted on teaching materials used by fourth grade students of MIN Boyolali, the students used textbooks for learning instead of module-type material. Specifically, the book discussing theme 8 (Daerah Tempat Tinggalku/My Living Place) subtheme 3 (Aku Bangga dengan Daerah Tempat Tinggalku/I am Proud of My Living Place) has connection between basic competence of the subject, yet its literary content is not correlated with Boyolali area, in which most stories only contain information outside Boyolali area. In fact, the theme and subtheme used as a bound material is the students' area, i.e. Boyolali. Derived from the existing condition, this research focuses more on developing character-based children literature module to increase critical thinking ability of fourth grades in MIN Boyolali on the theme of My Living Place subtheme I am Proud of My Living Place. This study is conducted as one of solutions to complete module need in MIN Boyolali and to foster good character in fourth grade students.

\section{METHOD}

Applying research \& development method, this study used the findings of the research to design a module that were systematically tested and evaluated to create an effective and efficient product scientifically (Gall, Gall, \& Borg, 2007: 589). The subject of this study was the students of class IV A, B, and C of MIN Boyolali. The subject of preliminary field testing consisted of 3 students of class IV $\mathrm{C}$ with high, moderate and low cognitive ability. Meanwhile, the main field testing comprised of different 6 students of grade IV C. For the operational field testing, class IV A was selected as the experimental group and class IV B as the control group. Those subjects were chosen using purposive sampling technique.

The research stages were adapted from the design made by Borg \& Gall i.e.: (1) \& (2) Need analysis through interviewing \& observing the teacher as well as analysis 
of teaching materials to find out the weaknesses of learning process undertaken by the teacher and to find solutions required by the teacher. From these stages, it was found that a learning module that covers character and critical thinking instilmentbased materials was required; (3) a preliminary module was then composed to be validated by the media expert and the material \& language expert to obtain suggestions or feedbacks for improving the quality of the module; (4) moving to the stage of preliminary field testing, the revised module was tested, with a class IV C teacher and three students from the same class as the subjects. The purpose of this stage was to gain information regarding teacher and students responses, to be used as consideration to develop the module. Based on the data gained from the previous stage, main product revision, main field testing, operational product revision, operational field testing, final product revision, and dissemination and implementation. The subjects of the research were st (5) In the main product revision stage, the data obtained was used to revise the product. The revised module was again brought to the experts to get input from the media expert and the material \& language experts. (6) After the input from the experts were applied to the module, the next step was to test the product in a broader scale that is main field testing. The subjects were the teacher, and other 6 students of grade IV $\mathrm{C}$ which were different from the three students from main field testing stage. (7) The data obtained, in the form of teacher and students response, were then used as guidelines to revise the module, which later would be tested in the operational field testing phase. (8) in operational field testing, quasi experimental method was implemented to monitor the effectiveness of the module in improving the ability to think critically. Therefore, two classes were given different treatment, as shown in the table.

Table 1. Non-Equivalent Control-Group Pre-Test Post-Test Design (modification by Creswell (2011: 310))

\begin{tabular}{cccc}
\hline Group & Pre-test & Treatment & Post-test \\
\hline EC & T1 & $X$ & T2 \\
\hline CC & T1 & - & T2 \\
\hline
\end{tabular}

Information:

KE: experimental class

KK: control class

T1: pre-test

T2: post-test

Data obtained from this stage, in the form of students' scores, was then measured using homogeneity test and $t$-test. The next step was final product revision, which aimed at producing a module that was feasible and effective for learning. 


\section{DATA ANALYSIS}

The data of this research were qualitative and quantitative data. Qualitative data was obtained from interview and observation from needs analysis stage. Meanwhile, quantitative data includes teacher response scores, student response scores, media expert validation results, material \& language validation results, posttest and pre-test of the students from experimental and control class. Qualitative data was analyzed and described qualitatively. Further, quantitative data from teacher's and students' response, media and material \& linguistic experts validation results were analyzed descriptively by using scale-five conversion reference after prior ordinal data were changed to interval one with the following guidelines:

Table 2. Item Scoring Criteria for The Questionnaire

\begin{tabular}{cc}
\hline Criteria & Score \\
\hline Excellent & 5 \\
\hline Good & 4 \\
\hline Average & 3 \\
\hline Fair & 2 \\
\hline Poor & 1 \\
\hline
\end{tabular}

Score obtained then summed and averaged, then converted to a value on the scale of 5, with reference table adapted from Widoyoko (2014: 144) as presented in the following table:

Tabel 3. Score Conversion on Scale of Five

\begin{tabular}{ccc}
\hline Value & Score Interval & Qualitative Data \\
\hline $\mathrm{A}$ & $\mathrm{X}>\mathrm{xi}+1,80 \mathrm{Sbi}$ & Excellent \\
\hline $\mathrm{B}$ & $\mathrm{Xi}+0,60 \mathrm{Sbi}<\mathrm{X} \leq \mathrm{xi}+1,80 \mathrm{Sbi}$ & Good \\
\hline $\mathrm{C}$ & $\mathrm{xi}-0,60 \mathrm{Sbi}<\mathrm{X} \leq \mathrm{xi}+0,60 \mathrm{Sbi}$ & Average \\
\hline $\mathrm{D}$ & $\mathrm{xi}-1,80 \mathrm{Sbi}<\mathrm{X} \leq \mathrm{xi}+0,60 \mathrm{Sbi}$ & Fair \\
\hline $\mathrm{E}$ & $\mathrm{X} \leq \mathrm{xi}-1,80 \mathrm{Sbi}$ & Poor \\
\hline
\end{tabular}

Information:

$\begin{array}{ll}\mathrm{Xi}_{\text {(ideal average score) }} & =1 / 2(\text { max ideal score }+ \text { min ideal score }) \\ \mathrm{Sbi} \text { (ideal deviation) } & =1 / 6(\text { max ideal score }- \text { min ideal score }) \\ \mathrm{X} & =\text { Empirical } / \text { actual score }\end{array}$

The data gained from post-test and pre-test of the students, on the other hand, was tested using t-test. This analysis was conducted to determine whether there was any difference in students' critical thinking achievement when using conventional learning (control class) compared to that of using module (experimental class). 


\section{DISCUSSION}

\section{Assessment of The Children Literature Module by The Material and Language Expert}

The module was validated by the material \& language expert based on the conformity of the material description with the core competence and basic competence, the accuracy of the material, the learning support material, the suitability of the learner's development level, the level of communicativeness of the language used, and the structure \& unity of ideas. The results of the assessments are presented in the following table.

Table 4. Results of Module Assessment by Material \& Language Expert

\begin{tabular}{|c|c|c|}
\hline Subcomponent & Indicator & Score \\
\hline \multirow{2}{*}{$\begin{array}{l}\text { the conformity of the material } \\
\text { description with the core } \\
\text { competence and basic } \\
\text { competence }\end{array}$} & Width of material & 4 \\
\hline & Depth of material & 4 \\
\hline \multirow[t]{2}{*}{ the accuracy of the material } & $\begin{array}{llll}\text { 3. Accuracy of facts and } \\
\text { concepts }\end{array}$ & 4 \\
\hline & Illustration accuracy & 4 \\
\hline \multirow{4}{*}{ learning support material } & $\begin{array}{l}5 . \quad \text { Conformity with the } \\
\text { development of knowledge }\end{array}$ & 4 \\
\hline & $\begin{array}{l}\text { U. Update of features, examples, } \\
\text { and references }\end{array}$ & 3 \\
\hline & 7. $\quad$ Contextual & 5 \\
\hline & $\begin{array}{l}\text { 8. Science, environment, } \\
\text { technology, and society }\end{array}$ & 4 \\
\hline \multirow{2}{*}{$\begin{array}{l}\text { the suitability of the learner's } \\
\text { development level }\end{array}$} & $\begin{array}{l}\text { 9. Compliance with the level of } \\
\text { thinking development }\end{array}$ & 5 \\
\hline & $\begin{array}{l}\text { 10. Compliance with the level of } \\
\text { emotional social development }\end{array}$ & 5 \\
\hline \multirow{3}{*}{$\begin{array}{l}\text { the level of communicativeness of } \\
\text { the language used }\end{array}$} & 11. Message understanding & 4 \\
\hline & $\begin{array}{l}\text { 12. Accuracy of grammar and } \\
\text { spelling }\end{array}$ & 4 \\
\hline & $\begin{array}{l}\text { 13. Standardization of terms and } \\
\text { symbols }\end{array}$ & 4 \\
\hline \multirow[t]{2}{*}{ the structure \& unity of ideas } & $\begin{array}{l}\text { 14. The integrity of meaning in } \\
\text { every meeting; the stages of learning } \\
\text { activities; and paragraph }\end{array}$ & 5 \\
\hline & $\begin{array}{l}\text { 15. Linkages between meetings; } \\
\text { paragraphs; and sentences }\end{array}$ & 4 \\
\hline Average & & 4.20 \\
\hline
\end{tabular}


The table above shows that the average score given by material and language experts was 4.20 . When referring to the scale- 5 of conversion table, the module was categorized into B or good, which is between 3.40 and 4.21 , and is above the minimum score (3.41) as described in the following diagram.

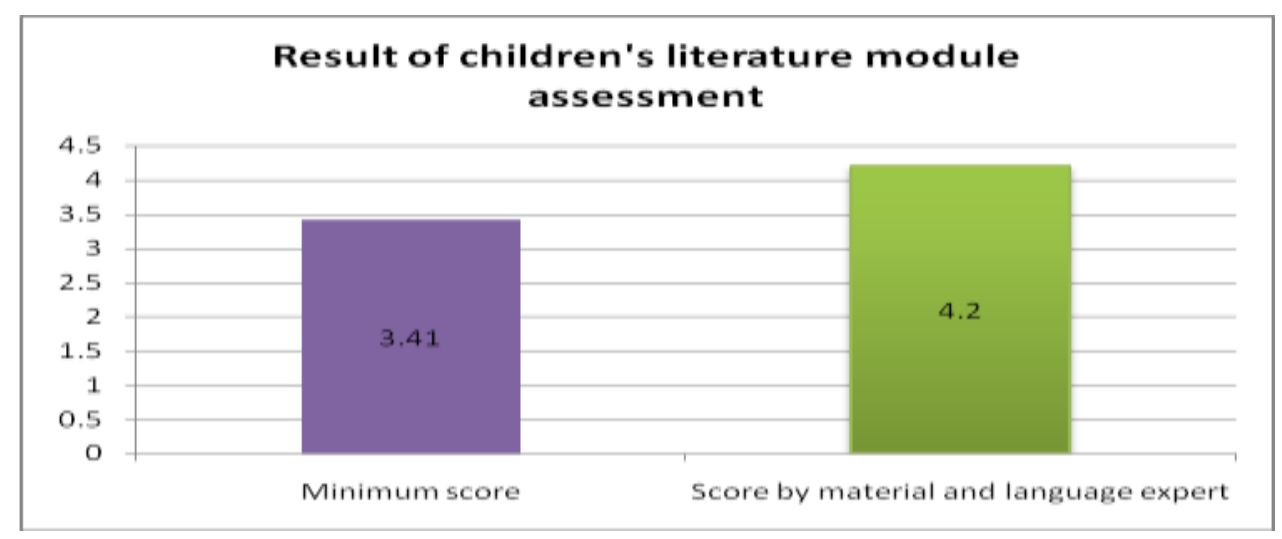

Picture 1. Diagram of Module Assessment by Material \& Language Expert

Furthermore, the scores of each subcomponent can be seen in the next page table.

Table 5. Results of Average Score Conversion by Material \& Language Expert

\begin{tabular}{llccc}
\hline \multicolumn{1}{c}{ Subcomponent } & Indicator & Score & Value \\
\hline $\begin{array}{l}\text { Conformity of material description } \\
\text { competence and basic competence }\end{array}$ & with core & 1,2 & 4 & $\mathrm{~B}$ \\
\hline accuracy of the material & 3,4 & 4 & $\mathrm{~B}$ \\
\hline learning support material & $5,6,7,8$ & 4 & $\mathrm{~B}$ \\
\hline suitability of the learner's development level & 9,10 & 5 & $\mathrm{~A}$ \\
\hline level of communicativeness of the language used & $11,12,13$ & 4 & $\mathrm{~B}$ \\
\hline structure \& unity of ideas & 14,15 & 4.5 & $\mathrm{~A}$ \\
\hline
\end{tabular}

Based on the table above, it can be concluded that in terms of material, children's literature-based module has a very high suitability with the level of learner development shown by the perfect score (5) and the category A (excellent). While based on the conformity of material description with core competence and basic competence, the accuracy of the material, as well as the learning support materials, the product is in category B (good). In terms of language, the structure and unity of ideas of the product are in the category A and communicativeness level of language is at level B.

\section{Assessment of The Children Literature-Based Module by Media Expert}

In terms of how media were attached, the module was assessed based on the feasibility of presentation that included presentation techniques, learning presentation, and presentation completeness. While from the aspect of fonts, the 
indicators scrutinized were related to module size design; cover layout; cover typography; contents layout; harmony, acceleration of understanding, and completeness of content layout; as well as illustration.

Tabel 6. Average Score Results by Indicators by Media Expert

\begin{tabular}{|c|c|c|c|c|c|}
\hline No. & Aspect & Indicator & Item & Total & $\sum$ Score \\
\hline \multirow[t]{3}{*}{1} & \multirow{3}{*}{$\begin{array}{l}\text { feasibility of } \\
\text { presentation }\end{array}$} & Presentation Technique & $1,2,3$ & 3 & 4 \\
\hline & & learning presentation & $4,5,6,7,8$ & 5 & 4.2 \\
\hline & & presentation completeness & $\begin{array}{l}9,10,11,12,13, \\
14,15,16\end{array}$ & 8 & 4.25 \\
\hline \multirow[t]{13}{*}{2} & \multirow[t]{12}{*}{ Graphics } & module size design & 17,18 & 2 & 5 \\
\hline & & cover layout design & $\begin{array}{l}19,20,21,22,23, \\
24\end{array}$ & 6 & 4.5 \\
\hline & & cover typography design & $\begin{array}{l}25,26,27,28,29, \\
30\end{array}$ & 6 & 4.83 \\
\hline & & Cover illustration design & $31,32,33$ & 3 & 4.33 \\
\hline & & $\begin{array}{l}\text { Consistency of Content } \\
\text { layout }\end{array}$ & $34,35,36$ & 3 & 4.67 \\
\hline & & $\begin{array}{l}\text { Harmony of Content } \\
\text { layout }\end{array}$ & $37,38,39,40$ & 4 & 5 \\
\hline & & $\begin{array}{l}\text { Completeness of content } \\
\text { layout }\end{array}$ & $41,42,43,44,45$ & 5 & 4.4 \\
\hline & & $\begin{array}{l}\text { The layout of the module } \\
\text { contents accelerates } \\
\text { understanding }\end{array}$ & 46,47 & 2 & 5 \\
\hline & & $\begin{array}{l}\text { Simplicity of content } \\
\text { typography }\end{array}$ & $48,49,50$ & 3 & 5 \\
\hline & & $\begin{array}{l}\text { Readability of content } \\
\text { typography }\end{array}$ & $51,52,53,54,55$ & 5 & 5 \\
\hline & & $\begin{array}{l}\text { Typography of the content } \\
\text { smoothes understand }\end{array}$ & $56,57,58,59$ & 4 & 4.5 \\
\hline & & $\begin{array}{l}\text { Illustration of content } \\
\text { clarifies and simplifies } \\
\text { understanding }\end{array}$ & $\begin{array}{l}60,61,62,63,64, \\
65\end{array}$ & 6 & 4.17 \\
\hline & Total & & & 65 & 4.25 \\
\hline
\end{tabular}

The table on the previous page shows the average score of the media experts at 4.25. When referring to the scale 5 conversion table, the product gets a very decent predicate (A), where the value is above 4.21 , and is above the minimum score of 3.41 .

The results of average score for each aspect can be seen in the following table. 
Table 7. Results of Average Score per Aspect by Media Expert

\begin{tabular}{cccc}
\hline No. & Aspect & Score & Value \\
1 & feasibility of presentation & 4.15 & $\mathrm{~B}$ \\
2 & Graphics & 4.70 & $\mathrm{~A}$ \\
\hline
\end{tabular}

The table above shows that in terms of media, aspect of graphics is superior over that of the feasibility of the presentation with the score of 4.70 and 4.15 respectively. This indicates that the former is in category A or excellent while the later is at the level $\mathrm{B}$, or good.

\section{Students' Response}

Having validated by the experts, the module was then tested to the students to gain their responses regarding its usability for learning. The two main aspects examined were to what extent the module could encourage independent learning and how friendly it was to the users.

Table 8. Results of The Students' Response

\begin{tabular}{|c|c|c|c|c|}
\hline No & Aspect & Indicator & Average & Value \\
\hline \multirow[t]{4}{*}{1.} & \multirow[t]{4}{*}{$\begin{array}{l}\text { Self } \\
\text { Instruction }\end{array}$} & $\begin{array}{l}\text { The material presented in } \\
\text { sequence to be understood easily }\end{array}$ & \multirow{4}{*}{ 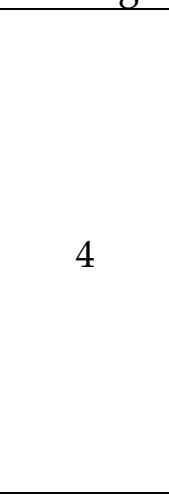 } & \multirow{4}{*}{ B } \\
\hline & & $\begin{array}{l}\text { The clarity of instructions in each } \\
\text { activity }\end{array}$ & & \\
\hline & & The suitability of time allotment. & & \\
\hline & & $\begin{array}{l}\text { The module composition eases } \\
\text { students to understand materials } \\
\text { independently with measured } \\
\text { guidance. }\end{array}$ & & \\
\hline \multirow[t]{4}{*}{2.} & User Friendly & Interesting module display & \multirow{4}{*}{4.3} & \multirow{4}{*}{ A } \\
\hline & & $\begin{array}{l}\text { The stories included in the } \\
\text { material completed by attractive } \\
\text { pictures. }\end{array}$ & & \\
\hline & & $\begin{array}{l}\text { The clarity of the passage in the } \\
\text { material and the activity. }\end{array}$ & & \\
\hline & & $\begin{array}{l}\text { The language used is } \\
\text { straightforward } \\
\text { communicative. }\end{array}$ & & \\
\hline \multicolumn{2}{|c|}{ Total score } & & 8.3 & $\mathrm{~A}$ \\
\hline
\end{tabular}

The overall score above shows that the average total score was 8.3 and therefore was in category A or "excellent". This means that based on the learners' opinion, the module was very interesting and encouraged them to study independently. While in terms of assessment per aspect, self instruction was in category B or "Good". On the 
aspect of user friendly, the score obtained was 4.3 with category A or "Excellent".

\section{Teacher's Response}

Based on the response of the teacher toward the module developed, the data obtained is presented as follows.

Table 9. Results of Teacher's Response

\begin{tabular}{|c|c|c|c|c|}
\hline No & Aspect & Indicator & $\begin{array}{c}\text { Avera } \\
\text { ge }\end{array}$ & Category \\
\hline \multirow[t]{6}{*}{1.} & \multirow[t]{6}{*}{ Module } & $\begin{array}{l}\text { Conformity of core competence, basic } \\
\text { competence, indicator to the material }\end{array}$ & \multirow{6}{*}{4.8} & \multirow{6}{*}{ A } \\
\hline & & $\begin{array}{l}\text { clarity of indicators to be achieved by } \\
\text { the students }\end{array}$ & & \\
\hline & & Accuracy of writing style & & \\
\hline & & $\begin{array}{l}\text { Stimulate the students' critical } \\
\text { thinking skills }\end{array}$ & & \\
\hline & & Module use instruction & & \\
\hline & & Layout & & \\
\hline \multirow[t]{5}{*}{2.} & \multirow{5}{*}{$\begin{array}{l}\text { Children } \\
\text { Literature }\end{array}$} & Prohibited elements & \multirow{5}{*}{4.8} & \multirow{5}{*}{$\mathrm{A}$} \\
\hline & & Language used & & \\
\hline & & Theme & & \\
\hline & & Characterization & & \\
\hline & & center of the story allure & & \\
\hline \multicolumn{2}{|c|}{ Total } & & 4.8 & $\mathrm{~A}$ \\
\hline
\end{tabular}

The results of the average total score above (4.8) indicates that based on the teacher's response in the questionnaire, the learning module was "excellent" and feasible to be used in operational field test. Specifically, in both aspects, the score were categorized with predicate A. Further, the feedback from the teacher was just to be consistent in designing the competence mapping between one learning session and the others.

\section{Results of The Module's Effectiveness Test}

The t-test was performed to determine whether there was any difference in critical thinking ability between control and experimental class. Firstly, normality and homogeneity tests were used as a prerequisite for analysis. The results are presented as follows. 
Table 10. Normality Test Results

\begin{tabular}{ccccc}
\hline Data type & Class & P value & Sig. level & Information \\
\hline \multirow{2}{*}{ Pretest } & experiment & 0.462 & Sig $>0.05$ & Normal \\
\cline { 2 - 5 } & control & 0.135 & Sig $>0.05$ & Normal \\
\hline \multirow{2}{*}{ Posttest } & experiment & 0.166 & Sig $>0.05$ & Normal \\
\cline { 2 - 5 } & control & 0.200 & Sig $>0.05$ & Normal \\
\hline
\end{tabular}

From the table above, it can be seen that overall, the $\mathrm{p}$ values in the pretest and posttest data of the experimental class and control class were more than the specified significance level, i.e. $(\alpha)=0.05$. In other words, Ho was accepted or the data has a normal distribution. When homogeneity test was performed, the $p$ value obtained in the pretest data was 0.325 . This means that the $\mathrm{p}$ value was greater than significance level (Sig> 0.05). Thus, Ho was accepted. While in the homogeneity test of posttest data, the $\mathrm{p}$ value was 0.13 , which shows that Sig $>0.05$ i.e. the significance value is greater than the specified significance level. Hence, it can be concluded both data is homogeneous. The next test performed after the data was proven normal and homogenous was independent sample $t$ test using SPSS 16.0 for Windows, which aimed to see whether there was any difference in critical thinking skills between students from control class and experimental class.

The hypothesis formulation was as follows.

$\mathrm{H}_{0}$ : There was no significant difference in critical thinking skills between the students who perform the lesson using children literature-based module and those who did not.

$\mathrm{H}_{\mathrm{i}}$ : There was significant difference in the ability of critical thinking between students who perform the lesson using children literature-based module and those who did not.

The result of the t-test is described in the following table.

Table 11. Effectiveness Test of Children Literature Module

\begin{tabular}{ccc}
\hline P value & Sig. level & Information \\
\hline 0.0001 & Sig $<0.05$ & $\mathrm{H}_{0}$ rejected \\
\hline
\end{tabular}

The result of independent $\mathrm{t}$-test shows that the variance of critical thinking ability ratio between the control and experiment class was in the value of 0.0001 . When compared with the significance level of $5 \%(\alpha=0.05)$, it can be drawn that the $p$ value was less than 0.05 ( $\mathrm{p} \leq 0.05 / 0.0001 \leq 0.05)$. This proves that there was significant difference between the control class and the experimental class, in which the students using the nationalism character-based module (in experimental class) for six times of learning process out performed critical thinking ability compared to those of who did not use the module (in control class).

After going through the independent sample t-test, in other words, the product of this research and development study, in the form of children literature module, 
was considered effective to improve students' thinking ability. The effectiveness of the product could of course be achieved after going through and meeting a series of development stages so as to produce a module that was worth-using. This was also proven by the data gained from the students' response who perceived that the module was excellent to be used for learning. That means students found it easy to use the module. It could be felt by them when they were able to learn at their own pace or when they found it familiar as it was interesting and systematic in terms of the design. This is corroborated by the opinion of Cengizhan (2008: 99) which states that "... is the modular instruction design that provides a flexible learning environment in its design, the active participation of students, and the opportunity for the students to progress at their own rate and make their own self assessment ".

In terms of the feasibility of the module in inculcating the character of nationalism through literature can be corroborated by the opinion of Logli (2015) who explains that the national identity is actually a feeling of a group towards the fundamental features that form the homeland or the same feeling of cultural similarity. In the other side, it is important to be understood that literature is a cultural product of a community system. This makes literature able to be used to instill character on the society, in this case the character of nationalism. The effectiveness of this children literature-based module in improving critical thinking skills could be seen based on the t-test result where $p$ value $(0.0001)$ was less than determined significance level ( $\mathrm{p} \leq 0.05 / 0.0001 \leq 0.05)$. This is also confirmed Ellen's statement in Santrock (2011: 3) that the fundamental element in critical thinking is the attentive attitude in daily activities. In correlation that, the developed module has proven eligibility to attract students' attention to use it for learning, accompanied by self-awareness to learn step by step of what made them interested during learning process.

\section{CONCLUSION}

The research and development $(\mathrm{R} \& \mathrm{D})$ procedures developed and implemented aimed to reduce the chances of failure and increasing the chances of successful study. However, along with the involvement of human element i.e. researcher in it, it will certainly experience certain level of limitations in the research conducted. The limitations in this study are as follows: (1) Limited material developed. This research only developed one sub theme due to the limited time in the study. Thus, the module generated could not closely embrace all the needs in the field. (2) The absence of empirical validation of the exercises used in measuring students' critical thinking skills. Validation employed was only restricted to that of the construct by the instrument expert. (3) The instilment of nationalism character through the developed module was only conducted in the scope of cognitive aspect. Whereas, the fundamental principle of character shaping is basically derived from a habit that is done repeatedly. For further research and the elementary school academic community, constructive suggestions are structured as follows: (1) Innovation in 
learning can be continuously performed in the future by, one of many, developing modules with broader material coverage which are emphasized on fostering positive values or characters suited with learning needs - not limited to a mere single subtheme. (2) The school should facilitate improvement effort in the learning process, in the context of this study that is the dissemination of the research findings will be more useful if it can be adopted by the teacher, or even more i.e. by adopting the method of module development. (3) Teachers should be able to enrich learning resources to be used by students in learning, for the reason that governmentpublished textbooks are sometimes not in accordance with the students environmental conditions. Therefore, it would be better for teachers to develop the module as another teaching material reference in order to encourage students' independent learning attitude in pursuing their needs.

\section{REFERENCES}

Cengizhan, S. (2008). Determining The Effect of Modular Instruction Design on The Academic Achievement and Long-Term Retention of Students with Different Learning Styles. Journal or Theory and Practice in Education, 4(1), 98-116. Retrieved from https://www.researchgate.net/publication/26499808_Determining_the_Effec t_of_Modular_Instruction_Design_on_the_Academic_Achievement_and_Long -Term_Retention_of_Students_with_Different_Learning_Styles

Chen, M. L. (2012). Effects of Integrating Children's Literature and DVD Films Into A College EFL Class. English Teaching: Practice and Critique, 11(4), 88-98. Retrieved from https://files.eric.ed.gov/fulltext/EJ999756.pdf

Creswell, J. W. (2011). Educational Research: Planning, Conducting, and Evaluating Quantitative and Qulitative Reearch (3rd ed.). Boston: Pearson Eduction.

Gall, M. D., Gall, J. P., \& Borg, W. R. (2007). Educational Research An Introduction (8th ed.). USA: Pearson.

Lickona, T. (1991). Educating for Character: How Our Schools Can Teach Recpect and Responbility. New York: Bantam Books.

Logli, C. (2015). Bhinneka Tunggal Ika (Unity in Diversity): Nationalism, Ethnicity, and Religion in Indonesian Higher Education. USA: ProQuest.

Santrock, J. W. (2011). Life Span Development. New York: McGraw Hill.

Saracho, O. N., \& Spodek, B. (2010). Families' Selection of Children's Literature Books. Early Childhood Education Journal, 37(5), 401-409. Retrieved from https://www.researchgate.net/publication/226789374_Families'_Selection_of _Children's_Literature_Books

Saxby, M., \& Gordo, W. (1991). Give Them Wings, The Experience of Childrens' Literature. Melbourne: The Maximilan Company.

Tomlison, C. M., \& Brown, C. L. (2002). Essentials of Children's Literature. Boston: Pearson Education.

Wibowo, A. (2013). Manajemen Pendidikan Karakter di Sekolah. Yogyakarta: Pustaka Pelajar. 
Widoyoko, S. E. (2014). Penilaian Hasil Pembelajaran di Sekolah. Yogyakarta: Pustaka Pelajar.

Zuchdi, D. (2009). Pembinaan Karakter melalui Pembelajaran Bahasa. In Seminar Nasional Inovasi Pembelajaran Bahasa dan Sastra dalam Rangka Pembinaan Karakter Bangsa di Era Globalisasi. Yogyakarta. 